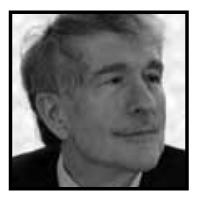

\title{
Commentary Getting at the Heart of the Creative Experience
}

\author{
Howard Gardner, Harvard University
}

\begin{abstract}
In this interview, developmental psychologist, professor, and author Howard Gardner describes his early interest in creativity and explains why he wanted to study creativity from a different perspective than what had been done in the past. He shares why studying creativity through the biographies of creative people provides more insight than using creativity tests that may be as limited as IQ tests. The creative leaders he studied in his book Creating Minds proved to have an unusual blend of intelligences-not just those intelligences obviously related to their field. He explains that creativity is about one's personality, the willingness to take risks, and being a certain kind of person rather than having a particular set of cognitive skills. Finally, he comments on creativity in today's society.
\end{abstract}

\section{How did you first become interested in creativity?}

$s$ a young person I was very much involved in music. After I went to college I spent a year in England and even though I was supposed to be in studying at the London School of Economics I spent most of my time going to theatre, opera, ballet, museums. I think that was sort of the beginning of my interest in the creative process from a scholarly point of view. When I was a graduate student in psychology I actually wrote a big literature review about creativity for Stanley Milgram who was a famous psychologist, now deceased, known for his study of the "obedience paradigm." I remember, he went over the paper pretty carefully, and he wrote in notes saying, "People who study creativity are a singularly uncreative lot." 
I don't know why he said that but it always stuck in my mind. I might say it was a stimulus or a motivator. I would add that while I think my interest in creativity came from the arts, I don't think creativity is particularly connected to the arts-I think you can have creativity in any realm from business to politics to technology. Many artists would hope they're creative but they may not be. The study of creativity is a longterm interest...I didn't write about it directly for 20 years after graduate school but it was always something in my mind.

How has your journey to understand creativity unfolded, and what were the milestones along the way?

I had this long-term interest in creativity but I really put it aside for work in more "canonical" developmental psychology and neuropsychology where creativity wasn't much on the agenda and where there were not, in my view, good methods for studying creativity. I'm best known for developing a theory of multiple intelligences in which I argued that intelligence shouldn't be viewed as a singular entity but rather people are capable of developing and displaying different kinds of intelligence. That got a lot of attention thirty years ago. When I began to speak publicly about this or to write in more popular venues, people would say, "Well, what about creativity? Is there one creativity or are there a bunch of creativities?"I hadn't really thought about that much before but I decided that I wanted to see whether there were specific forms of creativity which mapped in a certain way to different kinds of intelligence.

Around the middle of the 1980s I began to think seriously about that issue. First of all, I was never very happy with the so-called creativity tests, which were tests of divergent thinking. In fact, if I wanted to be brutal, I would say that divergent thinking tests are tests of creativity by people who don't really understand what creativity is all about. I think tests of divergent thinking basically show whether somebody is facile and can be entertaining at a cocktail party or maybe brainstorm well at some kind of mixed group at work. I think creativity is a much longer-term endeavour, which requires deep immersion in the subject matter, the development of skills, the capacity to ask questions that haven't been asked before and to spend as much time as necessary to come up with the best answers we can to those questions. Divergent thinking tests fall even shorter from the phenomenon of creativity than IQ tests fall from the phenomenon of intelligence. I was not going to go out and give a bunch of divergent tests to people in different domains to see whether their creativity was different. Instead, I made a decision to do biographies and to take individuals who were clearly creative-whether or not people liked them: they were clearly creative 
in specific spheres, and by argument, these people would be creative in different intelligences.

In your book, "Creating Minds" you have indicated that it was a pivotal moment when you shifted from the question, "What is creativity," to "Where is creativity?" Can you talk about this and explain why this was so helpful?

My book, "Creating Minds," came out in 1993 and has just been reissued in 2012 with a new preface, a new bibliography and new cover, which uncharacteristically I helped to design. In that book I studied seven people, each of whom I thought would be creative in a different intelligence. The list was: Einstein whom I saw as a logical, mathematical thinker; T.S. Eliot, the poet as linguistic thinker; Pablo Picasso, the painter, a spatial thinker; Igor Stravinsky, the composer as a musical thinker; Martha Graham, the dancer as a ballet-kinesthetic thinker; as "intrapersonal," Sigmund Freud, the founder of psychoanalysis; and "interpersonal," Gandhi, leader of people in India [over 60] years ago. My hypothesis was that each of them would be creative, reflecting their particular intelligence.

I selected people all of whom lived about 100 years ago, which meant, that on the one hand, we were far enough away that nobody would argue that any of them was not creative but recent enough so there was lots of data available. If you've studied Mozart, he's certainly creative, and I've written about Mozart, but the amount of data available about him or the amount of data available about Napoleon or Jesus Christ is pretty modest.

Interestingly, it didn't turn out that each of these people was strong in one intelligence and not in the others. In fact, what characterized them was more that they had an unusual blend of intelligences. [For example,] Freud saw himself as a scientist but he wasn't particularly good in logical, mathematical or spatial thinking but he was brilliant at language and in understanding other people and in understanding himself. He was a combination of linguistic and personal intelligences even though he saw himself as a scientist. Each of the people whom I studied, except for one, also had areas in which they were notably weak in-intelligences where they didn't stand out at all. The only exception from my study was Stravinsky, who I think was perfectly fine in his other intelligences. He probably could have been a lawyer; in fact he studied law, was quite gifted in the other arts. He wasn't a particularly nice person-I don't think he'd have any use for me-but I wasn't studying who was nice, I was studying who made creative use of different intelligences. 
This book is very different from other studies of creativity; it doesn't give tests to people, it doesn't [look at] people that are alive, although Martha Graham was alive during most of the time that I was working on this book. It relies on archival material. I think of all the books I've written, it was probably the most fun to do because I really immersed myself in the worlds of these people and tried to pretend that I was a friend of theirs and I could ask them questions and see what they were doing and thinking.

Can you discuss the fundamental things that you learned about creativity in your case studies of the "seven creators of the modern era?"

Probably the thing that surprised me the most was while these people were very sharp cognitively, what distinguished them more were their personalities. These were people who were very ambitious, wanted to make a mark - and here's the important part-were willing to take risks and didn't care if they failed. If you want to be creative you have to take risks - that's almost the definition of being creative, but yet if you don't succeed and you quit or kick the dog or jump out the window, you're not going to be creative. So when these people did their risk taking, and it didn't work out, rather than blowing their stack, they said, "What can I learn from this? How can I do better next time?" And then when they had a creative breakthrough-sometimes they knew it and sometimes the world told them-they didn't rest on their laurels, they were looking for other kinds of challenges, other places to take risks. Creativity, contrary to what I and many other people have thought, is not a one-shot thing; it's not even something that occurs at a particular moment. It's more a way of being, and the way of being probably starts very early in life. In fact, except for prodigies-Picasso was a prodigy; Mozart was a prodigy-most people form the personality of a creator before they figure out which area to be creative in. I mentioned that Stravinsky could have been a lawyer, certainly T.S. Eliot and Freud could have been conventional scholars-they were very good academically. But they were already people who weren't happy with the status quo and they wanted to try something new. Even though they might have been despondent if something didn't work, they got out of it and they tried new things. Creativity is really as much about personality, risk taking and being a certain kind of person rather than having a particular set of cognitive skills.

You asked, "What's the importance of asking the question, 'Where's creativity?' as opposed to 'What is creativity?"' This idea is not mine. It came from Mihaly Csikszentmihalyi, who is an expert in creativity. He actually took the "linguistic turn of phrase" from a teacher of mine, Nelson Goodman, who was a philosopher and who, 
instead of asking the question, "What is art," wanted to ask the question, "When is art?" Part of being a creative person, whether you're Mihaly Csikszentmihalyi or Nelson Goodman, is to ask a new question, and when Csikszentmihalyi asked the question, "Where is creativity?", this was like a breakthrough.

Everybody, including myself, thought creativity was all inside the head of the individual and most of our conversation so far has been about the individual. But in fact creativity is always emergent from three different sectors: one is the individual of whom we've been talking about until now, one is the domain in which individuals work, and one is the field which makes judgments.

To be specific, if you've got a bunch of painters, and they're all busy painting away, one question is, "How does their painting relate to what other people are doing?" Is it just copying, is it too far out? Does it represent a step forward or a step backward? But what the painter thinks, what the painter's mother thinks doesn't matter-it's what the field thinks. The field are all the taste makers and opinion makers in the area of the arts: people who decide who gets into art school, who graduates from art school, who gets displayed in galleries, who gets a positive review, who wins various rewards, and so on. You might say, "Well, that's the area of painting, it's very subjective. But what about mathematics, it's very objective: do you need a field there?" And the answer is, "absolutely [yes]." There are many people who are mathematicians, but you have to look at what mathematics they're doing and how it relates to what mathematics other people are doing. Does it copy what everybody else is doing, or is it going off into a promising direction? But, again, it doesn't matter what the mathematician thinks or his mother thinks. The question is, "What do informed people think?"

By a more funny coincidence, every few years there's an award given to the most original mathematician under the age of forty and it's called the "Fields Medal." And of course it's named after somebody who has nothing to do with "field" in the Csikszentmihalyi sense. But what it means is that even in mathematics we have to make judgments, and just as in painting, the judgment of the man in the street doesn't mean much. The judgment of informed people, whether it's gallery owners or givers of the Fields Medal, is very important. Csikszentmihalyi having phrased the question this way gave a whole additional push to the study of creativity.

I could add at this point I don't think social science is or should be a mere imitation of natural or physical science. What social scientists like Csikszentmihalyi and me do is come up with concepts. These are concepts that people may not have 
thought of before like "multiple intelligences" or "flow" and we try to call evidence out in favour of those concepts through experiments, observation, and argument. Then, if the concept, whether it's "multiple intelligences" or "flow" or Erik Erikson's notion of "identity" or Freud's notion of the "superego" or Max Weber's notion of the "iron law of bureaucracy," if those concepts proved useful to people who are thinking about these questions, then they gain a certain currency. Again, social sciences differ from the natural physical sciences, because sometimes when we write up a new finding it actually affects the way people are. When Erikson wrote about "identity," all of a sudden people had an identity crisis which they may not have had before. That's the way in which I think about my work on creativity, and probably one of the reasons I'm not that excited about creativity tests, because I don't think they get at the heart of the creative enterprise.

You have suggested that "creative capital" is developed in childhood. How can it be fostered and enhanced?

I think [there is] a good contrast between the prodigies whom I mentioned and other people who end up being equally creative. Prodigies-Picasso and Mozart are the prototypic examples-are individuals who have an incredible talent in an area, in this particular case in graphic representation or in music, and within five to ten years they become an expert and everybody says, "Wow, look at how representational Picasso's paintings are..." [or] "Look how readily orchestras can play what Mozart plays..." But most prodigies don't end up doing anything that the rest of the world cares about. They aren't judged as "creative" by the field, as I defined it earlier. And what has to happen basically with a prodigy if he or she is going to be judged as creative, is for that prodigy to acquire a personality which is more challenging, which doesn't simply try to do better what all these adults are already doing, but trying to go on in a new direction. It's probably not an accident that both Mozart and Picasso literally rejected their fathers. They were trained by their fathers. But rather than being loyal to their fathers, Mozart went away from his father, and Picasso actually changed his name-he used his mother's name rather than his father's name. There's kind of a rejection of the teacher, so one heads off in a new direction.

If you are a conventional creator-if that's not a contradiction in terms, as I said earlier-you first develop a kind of robust challenging personality and then you choose which domain you're going to work in but you don't choose it randomly. [For example], Einstein [could] probably have been a good mathematician as well as a good physicist, but we know he wasn't a particularly good violinist and he certainly 
wouldn't have been a good politician. The choice of domain is not random-it takes place in areas in which you already have some strength. You might say, "What is it in youth that involves the creation of capital on which you can draw later?" I don't think there's a high heritable component; I don't think people have creativity in their genes. I do think having a healthy constitution, being robust, not having to sleep all that much, probably has a genetic component. But much more important is the milieu in which you live. It's very hard to be creative if you live in a totalitarian environment where there are very strict rules about what you can do and what you can't do. There needs to be a certain tolerance for experimentation. It helps if your own family has got some iconoclasts in it: people who aren't just following the status quo but who are asking new questions. Probably, the conversation around the dinner table is important: is father just dictating what to do, is everybody just sitting there quietly, or are there vigorous discussions back and forth?

One of the fascinating things about the creative people I studied is that none of them was born, as far as I can recall, in a major metropolis. They grew up as kind of a big fish in a relatively small pond, but as soon as they became a middle adolescentthat's the age of eighteen, nineteen, twenty - they immediately moved to a big city, whether it was Vienna or London or Zurich or New York. The reason [for this] was that they'd already outgrown their little pond and they wanted to test themselves against the best and the brightest in the domains in which they were interested. Even though many of them became very difficult people as they got older (and I write about this), at the age of 20 they're all...characters like themselves, arguing, they would make common cause, they were kind of young rebels. That certainly has happened in our time in the United States: people would go to Silicon Valley or to Hollywood or to Wall Street. I would imagine in Canada many of them flocked to Toronto or on the west coast to Vancouver. One interesting question for students of creativity concerns the digital era where we can contact everybody online: "Will geography become less important or will it be as important as ever?" Richard Florida, who studies this issue, says geography continues to be important even though we can be in contact with people online; ultimately we want to be able to rub shoulders and elbows and make love and make war with our peers-we don't just want to do it via Facebook or Twitter but it's too early to know about that. 
In your book "Five Minds for the Future," you have said that what is needed in today's society is a "generous dollop of creativity in the human sphere" (p. 101). Can you talk further about this and suggest the implications this has for classrooms?

If you live in an environment where there's creativity all over the streetsand that would be the United States today with Hollywood and Silicon Valley, then the inculcation of creativity in the classroom isn't as important because the message is very vivid in the rest of the society. Even though that includes forms of creativity which are not ethical, about which I'll talk in a minute. But if you live in a society which is more top-down, more controlled, more cutting down the tall poppies, the high giraffes, then it is important for there to be creativity generated in the classroom [and] in the home because the message in society isn't that powerful. I'm going to use Canada as an example. If you live in the middle of Saskatchewan you're [probably] going to want to end up in Montreal or Toronto or Vancouver, and then even if you're very good in Canada you want to go to London or Paris or New York because it's a bigger pond and you want to lock your horns with people who are not in the country-which I think is a wonderful country—but it's not as much in the headlines as the places I've talked about.

Part of my answer to your question is; it depends on what the messages in society are. Another answer is, "What is the teachers' model?" If the teachers' model is the correct answer, then you better get to it as quickly as possible and if you don't get the correct answer "you're a dummy," then that's not going to foster creativity. But if teachers ask questions to which there are many answers or they analyze answers which are thought to be wrong to see how people got to them, then that's a much better message.

I have a story I would like to tell about the smart-ass kid who came up to me after a lecture about education. He held up his smartphone [and] said: "Why do we need school anymore when the answers to all our questions are in the smartphone?" And I thought for a moment, I said: "Yeah, the answers to all our questions except the important ones." The important ones are not going to be answered in smartphones and the teachers or parents or religious leaders or club leaders who convey that attitude are much more likely to spawn creative individuals than ones who think it's open and shut or "you can look it up in Google or Wikipedia," and that's end of the discussion.

When I talk about a "generous dollop of creativity in the human sphere," I'm really talking about ethics and morality. All the rewards for creativity now are for the 
latest app, latest technology, the ways in which you can invade privacy even more effectively than before, or diss or bully people more absolutely than before. But human nature seems not to have changed very much, and certainly not very much for the better since the time of the Greek city-states. Of course, we had a lot of dark ages. We had an enlightenment - the Enlightenment was wonderful for people who lived in France, England, Scotland, the United States, maybe Canada, but certainly didn't affect other parts of the world. A new enlightenment can't just be what Locke and Rousseau and Hume and Voltaire thought-it has to reflect the best thinking in our great traditions from all over the world as well as from some smaller societies which managed the issue of sustainability better than many of our larger and more avaricious and more iconoclastic societies.

My own work, as you may know now-it's not in intelligence, it's not in creativity -it's what I call good work: we're beginning to call our efforts the "good project" because we look at good persons, good workers and good citizens. (See www. thegoodproject.org.) We want to have people who don't just have a lot of money and a lot of power, we want to have people who want to do the right thing and go about trying to do the right thing. [However,] that involves a seismic change in how human beings relate to one another online and offline, how we make use of the best of our talent in the young as well as in the old, and how we judge people not just by how much disposable income they have but rather by what kind of contributions they make to society. I like to joke-and this is probably a good line to end on - that I always to look to see what Scotland and Canada do because Canada always does the opposite of the United States and Scotland always does the opposite of England, and in many ways Canada and Scotland are much saner. The problems in the United States are more visible and have more power...and so we have to change the big guys by learning from individuals, groups, and communities who may have a better idea of how to have a moral society but who don't receive the same attention as Washington or London do.

\section{References}

Gardner, H. (2007). Five minds for the future. Harvard Business School Press.

Gardner, H. (2012). Creating minds. Basic Books. 


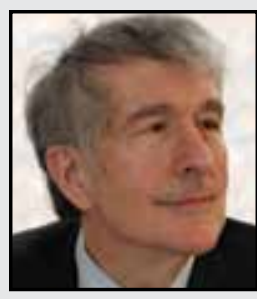

Howard Gardner is the John H. and Elisabeth A. Hobbs Professor of Cognition and Education at the Harvard Graduate School of Education. He also holds positions as Adjunct Professor of Psychology at Harvard University and Senior Director of Harvard Project Zero. Most recently, Gardner received the 2011 Prince of Asturias Award for Social Sciences. The author of twenty-eight books translated into thirty-two languages, and several hundred articles, Gardner is best known in educational circles for his theory of multiple intelligences, a critique of the notion that there exists but a single human intelligence that can be adequately assessed by standard psychometric instruments.

\section{LINKTO:}

http://www.howardgardner.com

http://www.thegoodproject.org 